\title{
Sangue, identidade e verdade histórica: crianças desaparecidas e memórias sobre o passado ditatorial na Argentina
}

\author{
Liliana Lopes Sanjurjo \\ Doutoranda em Antropologia Social (Universidade Estadual de Campinas) \\ lilisanj@yahoo.com.br
}

\begin{abstract}
Resumo Neste artigo trato da apropriação ilegal de crianças durante a última ditadura militar argentina (1976-1983). Procuro compreender como os integrantes das organizações de familiares de desaparecidos, ancoradas no parentesco de seus membros com as vítimas da repressão, reconfiguram suas identidades e legitimam suas estratégias políticas nas disputas pela consolidação de uma memória pública sobre o passado ditatorial recente. Explorando o tema da apropriação de crianças a partir da noção de evento crítico (DAS, 1995), analiso algumas polêmicas nacionais que envolvem o processo de restituição da identidade dos netos procurados pelas Abuelas de Plaza de Mayo. Tomo como objeto de análise os debates acerca da aprovação da Lei de $A D N$ para a resolução dos casos dos jovens apropriados que se recusam a submeter-se de forma voluntária ao exame de DNA. O intuito é explorar como noções sobre parentesco, sangue, identidade e verdade histórica atravessam as disputas pelas memórias.
\end{abstract}

Palavras-chave: Parentesco, identidades, memória, política, Nação.

Tuve mucho tiempo de búsqueda, y hace 2 años, sin tener elementos fuertes, le puse nombre a lo que buscaba: 'Soy hijo de desaparecidos', dije. Encontré la verdad hace 2 meses, cuando el análisis de ADN confirmó que soy hijo de Alicia y Damián. Ahora soy Juan Cabandié-Alfonsín. Soy mis padres, Damián y Alicia. [...] el plan siniestro de la dictadura no pudo borrar el registro de la memoria que transitaba por mis venas y me fue acercando a la verdad que hoy tengo. Bastaron los 15 días que mi Mamá me amamentó y me nombró, para que yo le diga a mis amigos, antes de saber quién era mi familia, antes de saber mi historia, que yo me quería llamar Juan, como me llamó mi Mamá durante el cautiverio en la ESMA. Este lugar estaba guardado en la sangre de Juan. [...] Hoy estoy acá, 26 años después, para preguntarles a los responsables de esa barbarie, si se animan a mirarme cara a cara y a los ojos, y decirme donde están mis padres, Alicia y Damián. Estamos esperando la respuesta que el punto final quiso tapar.

A s palavras são de Juan Cabandié Alfonsín, filho de desapaA recidos políticos, nascido na Escuela de Mecánica de la Armada (ESMA), um dos principais centros clandestinos de detenção da última ditadura militar argentina (1976-1983). ${ }^{1}$ Poucos dias após o seu nascimento, Juan foi entregue a um membro do serviço de inteligência da Polícia Federal da Argentina, que lhe ocultou por quase três décadas a origem criminosa e clandestina do vínculo que os unia como pai e filho.

1. O discurso de Juan foi proferido em 24 de março de 2004 na própria ESMA, em ato oficial realizado para as comemorações do aniversário do golpe militar, evento que formalizou a transformação desse local em um espaço de memória e de promoção dos direitos humanos. 
No ano de 2004, aos 26 anos de idade, após inúmeras desconfianças acerca de sua filiação, Juan procurou voluntariamente a organização Abuelas de Plaza de Mayo e se submeteu a um teste de DNA. Comprovou, assim, o seu parentesco biológico com um casal desaparecido. Isso foi possível mediante o cruzamento de suas informações genéticas com as das famílias de desaparecidos armazenadas no Banco Nacional de Dados Genéticos (BNDG). Seguindo o mesmo caminho de outros jovens apropriados, ${ }^{2}$ desde que Juan recuperou o seu nome e identidade original, tornando-se o neto restituído número 77 das Abuelas de Plaza de Mayo, rompeu afetiva e ideologicamente com aqueles que até então eram a sua família. Tornou-se um ativista pelos Direitos Humanos, elegendo-se deputado pela cidade de Buenos Aires.

No discurso de Juan ficam evidentes as conexões estabelecidas entre identidade biológica (filho de desaparecidos) e identidade política (identificação no campo político com os valores da militância setentista e do movimento de direitos humanos). Para Juan, se a verdade foi-lhe revelada pelo exame de DNA - "Encontré la verdad hace 2 meses, cuando el análisis de ADN confirmó que soy hijo de Alicia y Damián" -, os valores políticos igualmente parecem ser transmitidos pelo sangue - "la dictadura no pudo borrar el registro de la memoria que transitaba por mis venas". O seu discurso revela, de forma emblemática, como os domínios do parentesco e da política encontram-se, neste contexto específico, articulados e combinados.

O esforço empreendido na reconstrução da memória e da trajetória política dos tombados para, entre outras coisas, ressignificar suas próprias ações, parece ser um dos eixos norteadores dos familiares de desaparecidos dedicados ao ativismo pelos Direitos Humanos na Argentina. Partindo de uma perspectiva histórica e processual da cultura, julgo que o entendimento do campo de ativismo político desse movimento social exige, por meio da dilucidação de uma linguagem de combinação entre distintos domínios (Strathern, 1992), a compreensão das formas nativas de relacionar espaços sociais concebidos como de natureza e escalas diferentes (Neiburg, 2004), como o parentesco e a política, a família e a nação, o privado e o público, o natural e o social.

Este artigo trata das relações entre parentesco, política e memória nacional, no contexto do campo de ativismo dos familiares de desaparecidos na Argentina. ${ }^{3}$ A ideia central é refletir sobre em que medida e de que forma os domínios do parentesco e da política se combinam nos processos de construção das memórias sobre a ditadura nesse espaço nacional. Neste sentido, explora como as noções sobre parentesco - cujas representações, neste caso, estão em grande medida pautadas pela biologia/sangue/genética - são ressignificadas pelos familiares de desaparecidos em sua militância por Memória, Verdade e Justiça. O objetivo é analisar como esses familiares, ancorados nas relações de parentesco com as vítimas da repressão, atribuem sentido às suas próprias experiências e identidades, ao passo que encontram legitimidade social para suas demandas e ações políticas.

O artigo desenvolve tais questões a partir das polêmicas geradas pelo processo de restituição da identidade dos netos procurados pelas Abuelas de Plaza de Mayo. Para tanto, toma como objeto de análise os debates acerca da aprovação da Lei de ADN, sancionada em novembro de 2009 para a resolução dos casos de jovens apropriados na Argentina que recusam submeter-se de forma voluntária ao exame de DNA. Ao abordar o tema da apropriação de bebês a partir da noção de evento crítico (DAS, 1995) - no sentido de que se constitui como um evento que inaugura novas formas de ação histórica e que atravessa diversas instituições (família, Estado, agências multilaterais, sistema judicial, saber científico) -, o intuito é explorar como noções sobre parentesco, sangue, identidade e verdade histórica atravessam as disputas pelas memórias sobre o passado ditatorial na Argentina.

\section{A Lei de ADN}

O destino de Juan assemelha-se ao da maioria dos bebês desaparecidos durante a ditadura, cuja estimativa aponta para 400 casos. $^{4}$ Sequestrados junto

\footnotetext{
2. Apropriação é a categoria utilizada para fazer referência ao desaparecimento de crianças. Assim como os detenidos-desaparecidos, a apropriação emerge como categoria empregada pelo movimento de familiares das vítimas para denunciar o desaparecimento forçado de pessoas, neste caso, de crianças ("os desaparecidos com vida").

3. As reflexões apresentadas aqui estão baseadas em pesquisa de campo, bibliográfica e documental sobre o movimento de familiares de desaparecidos na Argentina, realizada no âmbito de um projeto de doutoramento do Programa de Pós-Graduação em Antropologia Social do IFCH/Unicamp, com financiamento da Fapesp. A etnografia foi realizada durante os anos de 2007, 2009 e 2010, totalizando 12 meses de pesquisa de campo. Foram entrevistados integrantes do movimento de familiares e analisados testemunhos publicados em outros meios (arquivo de história oral da associação Memoria Abierta). Foram também acompanhados atos públicos, homenagens, protestos, marchas, reuniões, audiências judiciais, seminários e demais atividades promovidas pelas organizações de familiares. No que se refere ao material produzido pelas próprias organizações e sobre elas, foram analisados: periódicos, material de divulgação (panfletos, cartazes, chamadas para eventos/atos/ manifestações), revistas, livros, literatura de testemunho, comunicados de imprensa, matérias de jornais, projetos de leis e documentação jurídica referente às causas judiciais reabertas após revogação das leis de anistia.
}

4. Em agosto de 2012, as Abuelas de Plaza de Mayo tornavam pública a resolução do $106^{\circ}$ caso, que resultou na restituição de Pablo Javier Gaona Miranda, sequestrado junto com seus pais em 14 de maio de 1978, quando tinha apenas um mês de vida. 
com os pais ou nascidos durante o cativeiro de suas mães, esses bebês foram apropriados por membros das forças de repressão, por famílias afins ou pelos próprios assassinos de seus pais. Numa atitude de pretensão salvacionista, as suas vidas foram poupadas, com a condição de que cresceriam dentro dos valores da "verdadeira família cristã argentina".

Socializados fora dos valores do "inimigo subversivo", o que se constituiu como um plano sistemático de apropriação clandestina de crianças, fechavam o elo da cadeia desaparecedora. Por um lado, eliminavam-se as marcas da morte: desaparecia-se com o corpo do inimigo, apagando seus rastros de existência, sua memória, seu local de sepultura e homenagem. Por outro lado, eliminavam-se as marcas da vida, sequestrando os filhos do inimigo, apagando a sua descendência a fim de evitar que o seu legado fosse transmitido para as gerações subsequentes. ${ }^{5}$ Desta forma, o "outro" era banido radicalmente da vida social. Utilizando uma metodologia que priorizou o desaparecimento forçado como principal metodologia repressiva, o autoproclamado Processo de Reorganização Nacional pretendeu refundar as bases da nação, procurando desaparecer com a memória, a descendência e a cultura política de um setor expressivo da sociedade argentina. ${ }^{6}$

Passados mais de trinta anos do golpe militar, no dia 26 de novembro de 2009 foi aprovado um projeto de reforma do Código Penal, impulsionado pela organização Abuelas de Plaza de Mayo, para a regulamentação dos procedimentos para a obtenção de DNA em investigações que procuram resolver os casos de apropriação de crianças durante a ditadura, conhecida como Lei de ADN. Esse novo artigo do Código Penal prevê que juízes que intervenham nesses casos, mediante a emissão de mandatos de busca, possam obter mostras de DNA por meios alternativos à inspeção corporal, tais como o sequestro de objetos que contenham células já desprendidas do corpo (sangue, saliva, pele, cabelo e demais tipos de provas biológicas).

A necessidade da criação desse instrumento jurídico deu-se diante da recusa de alguns jovens apropriados de se submeterem voluntariamente ao exame de DNA a fim de comprovarem o seu parentesco biológico com pessoas desaparecidas. Em contraposição àqueles que se apresentavam de forma espontânea à organização Abuelas, esses outros negavam o seu consentimento à extração de sangue, transferindo para o âmbito judicial a resolução do conflito referente à filiação.

Segundo um informe das Abuelas, a Corte $\mathrm{Su}-$ prema argentina decidiu em 2003 que uma jovem nascida na ESMA não podia ser submetida à prova sanguínea contra a sua vontade. Dessa decisão derivou a busca de vias alternativas para a restituição da identidade de jovens nascidos em cativeiro, garantindo a seus familiares biológicos o acesso à Justiça e à Verdade. A partir de 2006, juízes passaram a requerer a obtenção de material genético a partir de objetos de uso pessoal. Com tais precedentes, em agosto de 2009, a Corte Suprema dava aval a esse tipo de procedimento para determinar a identidade de supostos filhos de desaparecidos, e em novembro desse mesmo ano o projeto de lei foi promulgado pela então presidente Cristina Kirchner.

O conflito político, ético e jurídico que envolveu o debate sobre a Lei de ADN apresentava como dilema a seguinte questão: qual direito deveria prevalecer: o dos familiares da vítima ou o da vítima (o jovem apropriado)? Por um lado, argumentava-se que, sendo a apropriação de menores um delito de lesa humanidade e tendo em vista os compromissos assumidos pelo Estado mediante a celebração de pactos internacionais, haveria por parte deste o dever de sancioná-los penalmente, garantindo o direito dos familiares à verdade e à justiça (artigo 18 da Convenção Interamericana de Direitos Humanos). Recomendava-se, como dever do Estado, a criação de instrumentos para facilitar o esclarecimento da Verdade. Além do mais, com relação aos direitos dos apropriados, sendo o Estado signatário da Convenção da ONU sobre os Direitos da Criança, caberia a ele o dever de resguardar o direito da criança à identidade, garantindo, preferencialmente, uma filiação jurídica concordante com o fato biológico.

Em contrapartida, apresentavam-se argumentos a favor do direito dos apropriados à sua intimidade e integridade pessoal física, psíquica e moral (artigo $5^{\circ}$ da Convenção Interamericana de Direitos Humanos). Sob essa ótica, nenhuma pessoa poderia ser objeto de ingerência estatal abusiva em sua vida privada ou em domicílio, sobretudo tratando-se de medidas invasivas sobre o corpo da vítima (extração de sangue ou de células já desprendidas de seu corpo). Defendia-se que o direito à verdade não poderia prevalecer so-

\footnotetext{
5. Catela $(2001,2005)$ analisa em que medida o desaparecimento incidiu em dois eventos centrais nos processos de construção de pessoas e relações, no sentido de que tanto o nascimento quanto a morte demandam inscrições sociais para que um indivíduo forme parte de uma comunidade de pertencimento (familiar, étnica, política, nacional, classe social). Dessa perspectiva, analisa como o desaparecimento de corpos e de bebês provocou a desarticulação de identidades, seja pelo extermínio físico seja pela construção de identidades alternativas, neste último caso, mediante a inserção de crianças em famílias de militares. Para uma revisão das abordagens antropológicas que tratam dos processos de inscrição social nos rituais de início e fim da vida, ver: Kaufman e Morgan (2005).
}

6. O número de 30 mil desaparecidos é defendido pelas organizações de Direitos Humanos. Tais organizações calculam que para cada caso registrado existam mais três não notificados. O trabalho realizado pela Comisión Nacional sobre la Desaparición de Personas (Conadep) em 1984 contabilizou 8.961 casos de desaparecidos, número que não inclui exilados e presos políticos. Ver: Conadep (2009). 
bre o princípio do direito à intimidade e à integridade pessoal. Argumentava-se ainda que o Estado não poderia vulnerar o direito da vítima de se recusar a apresentar provas incriminatórias (o seu DNA) contra seus familiares.

Muitos dos apropriados que tiveram seus casos judicializados por se recusarem à extração de DNA, mas também muitos daqueles que recorriam às Abuelas voluntariamente, alegavam sentir-se responsáveis, caso cedessem à prova genética, pela prisão daqueles que os haviam criado. Os advogados de defesa das famílias apropriadoras destacavam que esses jovens estariam sendo revitimizados nesse processo, enquanto as Abuelas e os partidários da Lei de ADN sustentavam que esse instrumento jurídico retirava das vítimas a responsabilidade pela decisão de delatar ou não quem as criou; deixá-las com o peso da decisão implicaria numa violência ainda maior.

O crime de apropriação foi excluído das leis de anistia $^{7}$ pela adesão do Estado argentino à Convenção Internacional sobre os Direitos da Criança (1989), que com a reforma constitucional de 1994 foi incorporada à Carta Magna. A organização Abuelas participou ativamente da elaboração desse instrumento internacional, promovendo a inclusão de dois artigos, conhecidos como "argentinos", além de outro que trata do direito das crianças à identidade. Essa brecha jurídica permitiu que as Abuelas pudessem processar pessoas implicadas na apropriação. Por conseguinte, ainda nos anos 1990, a comprovação desse delito, mediante prova de DNA, levou famílias apropriadoras, ex-repressores, bem como diversas autoridades militares, à prisão.

A campanha das Abuelas pela restituição da identidade dos apropriados e pela aprovação da lei recebeu o apoio do governo nacional, de personalidades públicas e das demais organizações de familiares de desaparecidos. ${ }^{8}$ Mas também ganhava visibilidade o apoio de muitos dos netos restituídos. Estes haviam rompido com a família apropriadora e, desde então, reivindicavam a "verdadeira identidade" de filhos de desaparecidos (aqueles que eram lembrados por ter lutado e morrido por uma Argentina com mais justiça social). Além do mais, Alejandro Sandoval, o neto restituído número 84, cujo caso foi esclarecido em 2006 por via judicial, vinha a público manifestar a sua conformidade com o projeto de lei.
Vale lembrar que esses jovens restituídos, a partir da organização Abuelas de Plaza de Mayo e com os filhos de desaparecidos reunidos em H.I.J.O.S., vêm conformando uma nova geração de ativistas pelos Direitos Humanos na Argentina. Se durante a ditadura e no período de transição democrática as gerações ascendentes dos desaparecidos (mães e pais) protagonizaram a militância pelos Direitos Humanos, essa militância se viu renovada na década de 1990 pelos seus descendentes (seus filhos).

Esses jovens ativistas, herdeiros "naturais" das Madres e Abuelas de Plaza de Mayo e da militância setentista (desaparecidos, sobreviventes, assassinados, presos políticos e exilados), emergem como atores fundamentais do trabalho pela memória. Pautados no que entendem ser um duplo legado de ativismo político, essa nova geração se engaja na luta pela construção da memória pública sobre o passado ditatorial e sobre suas vítimas, dando continuidade à militância pelos Direitos Humanos e ressignificando as históricas demandas por Memória, Verdade e Justiça. ${ }^{9}$

A legitimidade do trabalho das Abuelas em prol da restituição dos apropriados, que contribuiu para a aprovação da Lei de ADN, encontra respaldo na ideia de que a nação argentina deve saldar as suas dívidas com o passado ditatorial para que possa consolidar-se como uma sociedade democrática. Nessa direção, é o Estado, por meio do poder judicial, que deve assumir a responsabilidade pelas violações aos direitos humanos cometidas na ditadura. Se no passado as resoluções dos casos de apropriação dependiam de iniciativas de coletivos de familiares das vítimas (como as Abuelas), hoje é o Estado, por meio da construção de um discurso público sobre o evento da apropriação, que articula as normas éticas e morais sobre o tema.

Nessa operação, a apropriação viu-se deslocada do âmbito familiar para tornar-se uma questão que diz respeito à nação argentina como um todo. É nesse sentido que a apropriação, assim como o desaparecimento forçado de pessoas, pode ser entendida, aqui, a partir da noção de evento crítico (DAS, 1995): além de atravessar a história das famílias afetadas e inaugurar novas formas de ação histórica (a conformação do movimento de familiares de desaparecidos), a apropriação tornou-se uma questão de Estado (que empreendeu ações para viabilizar a restituição das crianças sequestradas), jurídica

\footnotetext{
7. Em junho de 2005, a Corte Suprema argentina anulou as leis de anistia, alegando a sua inconstitucionalidade. Tais leis - Ley de Obediencia Debida (1987) e Ley de Punto Final (1986) - foram aprovadas durante a presidência de Raúl Alfonsín (1983-1989). Além disso, em 1989 o ex-presidente Carlos Menem concedeu indulto aos oficiais condenados e em 1990 estendeu os indultos às principais autoridades militares que haviam sido condenadas no Juicio a las Juntas em 1985. Ver: Roniger e Szajder (2004).
}

8. As organizações de Direitos Humanos argentinas, autodefinidas como organizações dos "diretamente afetados pelo terrorismo de Estado", são: Asociación Madres de Plaza de Mayo, Madres de Plaza de Mayo-Línea Fundadora, Abuelas de Plaza de Mayo, Familiares de Detenidos y Desaparecidos por Razones Políticas, H.I.J.O.S. (Hijos por la Verdad y la Justicia contra el Olvido y el Silencio) e Herman@s de Desaparecidos por la Verdad y la Justicia.

9. Para um trabalho que trata do processo de constituição do movimento de H.I.J.O.S. e a forma como ele ressignificou a memória dos desaparecidos, ver: Bonaldi (2006). 
(por meio da formulação de uma legislação específica), assim como científica (mediante o desenvolvimento de técnicas que permitissem comprovar a filiação).

Desde o seu surgimento em 1977, a organização Abuelas procurou articular uma rede de apoio internacional, sobretudo a partir de entidades multilaterais, como OEA e ONU, para amparar o trabalho de restituição da identidade dos apropriados. Com o retorno da democracia em 1983, as Abuelas passaram a reivindicar do Estado a criação de instrumentos institucionais e legais para facilitar a tarefa de busca e determinação da identidade das crianças desaparecidas. Foram assim criados o Banco Nacional de Datos Genéticos (BNDG) ${ }^{10}$ em 1987, a Comisión Nacional por el Derecho a la Identidad (Conadi) ${ }^{11}$ em 1992, bem como conformou-se a Red Nacional por el Derecho a la Identidad ${ }^{12}$ em 1993.

No início dos anos 1980, as Abuelas mobilizaram a comunidade científica internacional com o Programa de Ciências e Direitos Humanos da Associação Americana para o Progresso da Ciência, para avançar em estudos genéticos que pudessem determinar a maternidade e a paternidade ampliada. Esse foi um passo fundamental para a identificação de crianças que tinham pais desaparecidos e que só contavam com familiares indiretos (avós, tios, primos) para a determinação da identidade genética. ${ }^{13}$

Desta forma, pode-se afirmar que as Abuelas não estavam apenas criando uma estrutura de legitimidade para o Estado, mas também aprendendo a organizar suas demandas para esse novo Estado. Além do mais, buscavam tornar socialmente legítimo o imperativo moral referente ao dever do Estado, bem como da sociedade argentina como um todo, de garantir aos apropriados o direito à restituição de suas "verdadeiras" identidades.

A partir de 2003, com a assunção de Néstor Kirchner à presidência do país, as demandas do movimento de Direitos Humanos transformaram-se em política de Estado, tornando-se, nesse processo, emblema e marca da Era Kirchner. Foi estabelecido, assim, com as organizações de familiares, o monopólio sobre os pronunciamentos éticos relacionados ao passado ditatorial. A apropriação do tema ditadura por parte do governo trouxe o passado ditatorial, os desaparecidos e seus familiares para o centro da vida política argentina.

As demandas do movimento ganharam desde então maior legitimidade social: justiça e condenação dos perpetradores de crimes de lesa-humanidade; esclarecimento do destino dos desaparecidos; restituição da identidade dos apropriados; reivindicação dos ideais políticos defendidos pelos tombados; construção da memória coletiva sobre os desaparecidos e sobre o passado ditatorial recente. Longe de haver um consenso em torno dessas demandas, seja no interior do movimento de familiares, seja com relação a outros setores da sociedade, tais exigências constituem um campo permanente de disputa política, sobretudo no que se refere aos sentidos atribuídos à memória da ditadura e das vítimas ou sobre os meios mais apropriados para fazê-lo.

Posto isto, cabe perguntar: em que medida noções sobre parentesco, que neste contexto pautam-se em grande medida na biologia e na genética, são ressignificadas politicamente pelo movimento de familiares de desaparecidos? Como, ao ressignificarem as fronteiras entre a família e a política, esses familiares atribuem sentido às suas experiências e identidades, ao passo que encontram legitimidade para suas demandas e ações (como a aprovação da Lei de ADN)? Quais os efeitos sociais do protagonismo do parentesco para o movimento de Direitos Humanos e qual é a sua incidência na política argentina contemporânea? Quais são as representações atribuídas aos laços familiares (e biológicos) que tornam as vozes dos familiares as mais autorizadas para definir as narrativas sobre a ditadura? Como esses familiares vinculam tradições e heranças familiares, identidades políticas (deles próprios e de seus desaparecidos) na sua militância pela construção da memória sobre o passado ditatorial?

\section{Sobre a legitimidade dos laços de sangue}

Lo que nos une son los lazos ideologicos, políticos y sanguineos. ${ }^{14}$

10. O BNDG funciona em Buenos Aires, no Hospital Carlos A. Durand. A sua função é armazenar as informações genéticas das famílias de desaparecidos até o ano de 2050, com o intuito de facilitar o esclarecimento de conflitos referentes à filiação.

11. Como um órgão do Ministério da Justiça e Direitos Humanos, a Comissão foi criada com o objetivo de localizar as crianças desaparecidas durante a ditadura. Posteriormente, seus objetivos se ampliaram diante das denúncias de roubo e tráfico de menores. Embora seja um órgão estatal, o trabalho da Comissão é realizado de forma conjunta com a organização Abuelas de Plaza de Mayo.

12. Consiste numa rede nacional, com pontos de atendimento em todas as províncias argentinas, que atua como ponte entre os jovens que suspeitam ser filhos de desaparecidos, as Abuelas de Plaza de Mayo e a Conadi.

13. Para um histórico da trajetória das Abuelas de Plaza de Mayo, com relação à aplicação da genética no campo dos Direitos Humanos, ver Abuelas de Plaza de Mayo (2008).

14. Depoimento de militante de H.I.J.O.S., filha de desaparecidos e irmã de uma jovem apropriada, cuja identidade foi restituída em 2008. Fonte: Memoria Abierta, Testemunho de María Verónica Castelli, Buenos Aires, 2002. 
La identidad es una sola, una. Puede ser una identidad falsa, una identidad creada que nos es la verdadera. Adentro uno lleva cosas del papá y de la mamá que no se las borra nadie. Ninguna crianza puede borrar esa genetica del papá y de la mamá. Cuando nosotros encontramos un nieto que ya es un hombre o una mujer, esa crianza con esa gente falsa es como una cáscara. Cuando él sabe quien es y se identifica con su familia, con la historia de sus padres, esa cáscara se cae porque es fictícia, es falsa. No es él, es una cáscara. Sale el chico, el que fue el proyecto de un papá y de una mamá. No se puede cambiar lo que se lleva en la sangre. ${ }^{15}$

O desaparecimento forçado e a figura do detenido-desaparecido são hoje a principal marca do passado ditatorial na Argentina. As memórias da ditadura estão em permanente debate na esfera pública e marcam o seu lugar no imaginário nacional. Há mais de trinta anos o movimento social conformado pelos familiares das vítimas, bem como por sobreviventes (os aparecidos), procuram manter presentes as demandas por Memória, Verdade e Justiça.

Como também observado em outros contextos nacionais, durante o período militar as autoridades fizeram amplo uso de metáforas referentes à família e à biologia, como forma de fundamentar suas ações repressivas e o controle social. A nação foi representada como uma "grande família", sendo ressaltada como valor fundamental da nação (formando a tríade juntamente com "Pátria y Hogar"). A "subversão" era vista como "célula degenerada" ou como "câncer" que deveria ser eliminado para não contaminar o "organismo" nacional (Filc, 1997). ${ }^{16}$ Como reação em espelho, foi a família que organizou a oposição à ditadura, bem como foi a família, com o ativismo dos familiares de desaparecidos, que se tornou, no período democrático, a voz mais legítima para construir a memória pública sobre as vítimas e para definir as narrativas sobre o passado ditatorial.

Quando comparadas, no contexto latino-americano, as respostas políticas, sociais e jurídicas aos regimes ditatoriais, sobretudo quando se comparam os diferentes processos engendrados nos países do Cone Sul, veem-se como tais respostas constituíram-se de maneiras bastante distintas. O movimento pela permanência das memórias sobre a ditadura e sobre os desaparecidos cobra força significativa no contexto argentino, bem como se observa um processo permanente de rememoração. Igualmente, a importância política alcançada pelas organizações de Direitos Humanos, sobretudo em sua vertente familiar, ${ }^{17}$ não encontra paralelo nos demais países da região, ao menos no que se refere à sua repercussão social e política. ${ }^{18}$ Essas organizações continuam ativas no cenário político contemporâneo, e não somente aquelas que se gestaram na década de 1970 - Familiares de Detenidos y Desaparecidos Por Razones Políticas, Madres e Abuelas de Plaza de Mayo -, mas também aquelas que se constituíram nos anos 1990 por filhos de desaparecidos, como o H.I.J.O.S.

O uso de referências das relações de parentesco no campo político funciona aqui tanto em seu sentido literal quanto metafórico. Literalmente são mães, esposas, pais e filhos de desaparecidos, irmãos de jovens apropriados, netos de militantes de Familiares, Madres e Abuelas de Plaza de Mayo, bem como muitos dos jovens restituídos por Abuelas que entram na cena política na luta por memória, justiça e reparação. Dessa forma, são as concepções hegemônicas do parentesco, pautadas em conexões estabelecidas entre vínculos biológicos, sanguíneos e simbólicos, que são ressignificadas pelos familiares e que constituem seus discursos e ações políticas. Já em seu sentido metafórico, as Madres se transformaram em mães dos "30 mil detenidos-desaparecidos" (processo que denominaram "socialização da maternidade"), os filhos de desaparecidos se apresentam como irmãos, assim como as Abuelas se consideram avós dos 400 netos apropriados. Neste outro sentido, as relações de parentesco funcionam como metáforas para o estabelecimento de "novas famílias" entre as vítimas da repressão.

De forma crescente, os familiares que integram o movimento de Direitos Humanos passaram a associar a sua identidade como familiar de desaparecido a determinados valores políticos, pautados pelos vínculos que estabelecem entre tradições familiares e a transmissão da militância política através das gerações. Por conseguinte, acabaram combinando laços familiares e políticos.

Yo vengo de una familia de inmigrantes españoles. [...] Papá cuando vino se hizo anarquista. [...] se puso a laburar y a luchar con los obreros anarquistas de ese momento. Por eso él estuvo hasta detenido y todo, estuvo preso. [...] Yo creo que en la decada del 60

15. Declaração de Estela Carlotto, presidente das Abuelas de Plaza de Mayo, no filme-documentário Do You Know Who you Are? (Argentina, 2006. Direção/realização: Fulvio Arrichello).

16. A partir de declarações públicas das autoridades militares, Filc (1997) reconstrói os discursos da Junta Militar, apontando para a centralidade do uso de imagens da família e da biologia como metáforas da nação durante o período ditatorial.

17. Para uma análise da perspectiva de gênero do movimento de familiares de desaparecidos durante o período de transição democrática, ver: Feijoo e Gogna (1987).

18. Embora coletivos de familiares de vítimas da repressão policial/estatal tenham se formado em diversos países latino-americanos, essas organizações não possuem, no âmbito nacional, a projeção política alcançada pelo movimento de familiares de desaparecidos na Argentina. Existem, por exemplo, coletivos de H.I.J.O.S. no Chile, Uruguai e Guatemala. Sobre a trajetória de H.I.J.O.S. no Uruguai, ver: Sempol (2006). 
empieza a movilizarse un espírito crítico en la juventud, logicamente. La revolución de Cuba, el mayo francés, la pós-guerra también. Había muchos factores que influían. Y la gente más progresista, sobretodo descendiente de esa cantidad de anarquistas que hubo en el país, de socialistas y también comunistas, hicieron que los hijos fueran viendo más claro algunas cosas. Por ejemplo, yo no milité nunca pero mi simpatía estaba siempre con una idea socialista. [...] Se organizaron, hubo lucha armada. Si bien mi hijo no perteneció nunca porque no quería saber nada con las armas. Su proyección era ideológica, no violenta. Estaban juntos, había Montoneros, había PRT. Después entró en la universidad y lógico mucho más. Y a mi me parecía correcto, me parecía muy bien. Si mi papá había luchado. ${ }^{19}$

A legitimidade atribuída aos vínculos familiares reflete a importância do lugar que tais relações ocupam na vida social, repercutindo em práticas políticas. Além do mais, as representações atribuídas ao sangue e à biologia, neste caso, as substâncias transmissoras de tradições e identidades políticas, demonstram como para os familiares de desaparecidos a noção de parentesco combina o domínio da natureza com o da política.

Mi hijo Norberto, desaparecido, militó porque, bueno, ponele que los genes del padre... Yo, el 17 de octubre del 45, yo tenía 15 años en ese entonces, y de casualidad, por un hecho muy casual, me encuentro el 17 de octubre en la Plaza de Mayo. [...] y desde ahí empezé a militar en el peronismo. En ese peronismo de Perón y Evita, por las reivindicaciones sociales al trabajador, que más que la parte económica, que la redistribuición del trabajo, fue la dignidad que le dió al obrero. [...] Cuando vino el peronismo y puso esas leyes, ley de jubilación, ley del trabajo de las 8 horas obligatorias, vacaciones, todas esas cosas que el obrero no las conocía [...] Cuando viene el golpe del 55, empezamos la lucha del peronismo jóven. Yo tenía 25 años en ese entonces. Conformamos esos grupos de "luche y vuelve", que era un grupo que se conformó del peronismo, que luchábamos... pero no la lucha armada, sino la lucha de panfletiar, escribir en las paredes "Perón vuelve" y todas esas cosas. ${ }^{20}$

A inserção das novas gerações (os filhos e netos de desaparecidos) na militância pelos Direitos $\mathrm{Hu}-$ manos e na luta pela construção da memória parece seguir o curso da cadeia geracional: a apropriação do capital político e a ressignificação das identidades e de projetos políticos pelas gerações descendentes.

Que somos quienes van a seguir después que las $\mathrm{Ma}-$ dres o las Abuelas no estén. Creo que es eso. Y saber que sos la hija de una persona que luchó por un ideal, que hubo un montón de gente que lucharon por sus ideales y que dejaron una buena herencia acá. ${ }^{21}$

Como corolário, as relações de parentesco com as vítimas da repressão converteram-se em justificativa para as ações políticas impulsionadas pelo movimento de familiares, assim como atribuíram legitimidade aos seus discursos. Conforme salienta Jelin (2007, p. 39), a propriedade do tema da ditadura acabou ficando atrelada, ou até mesmo fundindo-se, com a posição dos "diretamente afetados": "La propia noción de 'verdad' y la legitimidad de la palabra (o, si queremos ser más extremos, la 'propiedad' del tema) llegaron a estar encarnadas en la experiencia personal y en los vínculos genéticos". Neste sentido, vale problematizar em que medida essa autoridade simbólica implicou numa demanda do monopólio da "verdade" e dos sentidos atribuídos às memórias da ditadura: a "verdade" é revelada aqui pela voz, pelo sangue e através do corpo dos afetados diretos. 22 "Por razones biológicas somos los que vamos a continuar la memoria. Para eso estamos todos juntos." 23

Essa noção de "verdade" atrelada à biologia e ao sangue vem sendo ressignificada pelos filhos de desaparecidos que integram H.I.J.O.S. e Abuelas de Plaza de Mayo. O sentido de suas ações parece basear-se na prerrogativa moral de que, na condição de descendentes das vítimas, possuem o dever histórico e familiar de continuar a luta contra a impunidade e o esquecimento. Como bem aponta Fried (2001, p. 142), "esta corporización o encarnamiento de las me-

19. Depoimento de uma mãe integrante da Asociación Madres de Plaza de Mayo. Seu filho foi sequestrado no dia 10 de maio de 1976 . Fonte: Memoria Abierta, Testemunho de María del Rosario Cerruti, Buenos Aires, 2006.

20. Depoimento de Julio Morresi, integrante de Familiares de Desaparecidos y Detenidos por Razones Políticas. O seu filho desapareceu em 23 de abril de 1976, aos 17 anos idade. A entrevista foi realizada no dia 21 de setembro de 2009, na sede da organização em Buenos Aires.

21. Depoimento de Lorena, filha de desaparecidos e ativista de Abuelas de Plaza de Mayo. Seus pais estão desaparecidos desde o dia 31 de agosto de 1977. No momento do sequestro, sua mãe estava grávida de seis meses. Lorena procura um irmão que nasceu em cativeiro no final de 1977. Fonte: Memoria Abierta, Testemunho de Selva Lorena Battistiol, Buenos Aires, 2001.

22. Para uma análise das relações entre legitimidade política e vínculos familiares nas disputas pela construção da memória sobre a ditadura na Argentina, ver: Jelin $(2002,2007)$. Para uma análise crítica acerca da literatura de testemunho (centrada na primeira pessoa e nos relatos da experiência pessoal-corporal), sobre o boom desse gênero no contexto pós-ditatorial e sobre a relação dessa produção literária com os temas da Memória, História e Verdade, ver: Sarlo (2007).

23. Depoimento de Guadalupe, filha de desaparecidos (Gelman; Lamadrid, 1997). 
morias parece ser un importantísimo impulso para ese sentimiento de responsabilidad del que muchos hijos hablan”. A militância de H.I.J.O.S. dirige-se a marcar com sua presença a ausência de seus pais desaparecidos. Se, como afirmam, a ditadura procurou eliminar a vida, o projeto político e os corpos dos desaparecidos, eles aparecem para demonstrar que o projeto militar de banimento radical do "inimigo" não se concretizou conforme o previsto.

Yo nací en la Escuela Superior de Mecánica de la Armada. [...] Cuando nací, estuve aproximadamente 20 días con mi mamá y luego los militares me roban de los brazos de ella y me entregan a una familia militar. Entonces a mí me falsearon la identidad, el nombre, la fecha de nacimiento, me falsearon todo [...] Nosotros estamos vivos y ustedes no nos ganaron. Ustedes no pudieron cumplir su plan macabro de robos de bebés. Porque todavía seguimos y continuamos con las ideas de nuestros padres. Y decirles en la cara de ellos que creemos, que lo vamos a trabajar y lo estamos haciendo para que un mundo mejor sea posible. ${ }^{24}$

As conexões entre identidade familiar (e biológica) e identidade política ficam mais evidentes no caso dos apropriados. Com a restituição, esses jovens não assumem apenas um novo nome e uma nova filiação, inserindo-se no grupo familiar de seus pais biológicos, mas também assumem uma nova identidade política e o legado que implica ser familiar de desaparecido na Argentina. Desta forma, muitos desses jovens restituídos passaram a ser voz ativa no movimento de Direitos Humanos ou integraram-se à política formal por meio da participação em partidos políticos. Em seus discursos, são comuns afirmações como "o que se leva no sangue não se apaga”, para demonstrar que, embora tenham sido criados dentro dos valores do "inimigo", herdaram os valores políticos e a vontade de "militar" de suas famílias biológicas.

Cuando te devuelven tu identidad y vos te das cuenta cual es tu nombre, cuando sabés que te dieron un nombre, y te hacés cargo de ese nombre, de la historia de ese nombre y empezás a hacerte cargo de lo que sos vos, empezás a construir lo que tendría que haber sido tu vida siempre. Yo siento que es empezar a despertar la sangre que siempre estubo dormida, que siempre estubo ahí. A nosotros nos gestaron con amor, nos soñaron de una manera. [...] Y vos sabés que cuando recuperás la identidad, te das cuenta que vos ganaste, que no consiguieron lo que querían. Que vos tenés tu nombre, vos sabés de dónde venís, para qué te soñaron. [...] Y empezás a construirlo todos los días. O sea, a formar tu carácter, el que siempre estubo dormido. Porque esa era la idea, dormirlo. Eso es recuperar la identidad. Y a parte es recuperar tu dignidad, condición de ser humano. [...] yo tengo un nombre, tengo un apellido, tuve una mamá y un papá. Los tengo, no están conmigo, pero sigo teniéndolos. Y son los que me sostienen. ${ }^{25}$

Essas narrativas demonstram como genética, sangue, identidade política e verdade histórica encontram-se identificados quando se trata dos filhos de desaparecidos que se incorporaram à luta pelas suas memórias. Os legados familiar e político combinam-se, reforçando uma interpretação em que o sangue, como substância espiritual, corporal e genealógica, estabelece a relação e a verdade histórica. Tendo pais desaparecidos por motivos políticos, os filhos (assim com as mães o fizeram) assumem o dever da memória, da construção da "verdade" histórica e de marcar uma identidade que se expressa também em termos políticos. Política, militância e memória parecem ser transmitidas aqui pelas gerações.

Cabe destacar que geração funciona como ferramenta conceitual central, visto que o movimento de familiares se define pela memória de eventos e dramas sociais compartilhados (o passado ditatorial e o desaparecimento forçado), assim como pela relação de temporalidade estabelecida entre aqueles que antecedem e sucedem os detenidos-desaparecidos na cadeia genealógica do parentesco. Geração constitui assim um dos referenciais no processo de construção dos detenidos-desaparecidos como categoria social (generación de los 70', juventud de los 70'). Além do mais, geração é chave para o entendimento dos familiares como atores políticos (Abuelas, Madres, H.I.J.O.S.): é a cadeia genealógica que estabelece os nexos desses ativistas com as vítimas da repressão e que articula a incorporação de legados familiares e políticos.

Pensando na cadeia geracional, se os desaparecidos encontram-se identificados como geração e são seus familiares os protagonistas na construção de sua memória, torna-se pertinente relevar quais as transformações que o engajamento da geração deles descendente provocará na construção de sua imagem. Se num primeiro momento foram as mães que falaram pelos desaparecidos e atribuíram sentidos às suas trajetórias, posteriormente o vazio deixado pela geração

24. Depoimento de Juan Cabandié, filho de desaparecidos apropriado quando bebê, no filme-documentário Do You Know Who you Are? (Argentina, 2006. Direção/realização: Fulvio Arrichello).

25. Depoimento de Hilda Victoria Montenegro, filha de desaparecidos e apropriada por um coronel do exército que teve participação direta no assassinato de seus pais. A sua identidade foi restituída em julho de 2000. Entrevista realizada por Abuelas de Plaza de Mayo em outubro de 2010. Disponível em: <www.abuelas.org.ar>. Acesso em: 24 abr. 2012. 
desaparecida será preenchido com novos conteúdos pelos filhos, que falarão de um novo lugar, seja pela posição que ocupam na cadeia genealógica, seja pelo contexto histórico e político a partir do qual evocam suas interpretações sobre o passado.

Com a crescente participação dessa nova geração no movimento de familiares, inicia-se um processo de inscrição dos desaparecidos na memória nacional como sujeitos históricos, portadores de identidades, projetos e práticas políticas. Como bem apontado por Vecchioli (2001), a análise da trajetória de construção dos desaparecidos como categoria social - cujo percurso parte da negação absoluta da existência dos desaparecidos no espaço nacional e culmina na reivindicação deles como atores políticos - é reveladora das disputas que diversos agentes empreendem com o objetivo de atribuir-lhe um sentido específico. Além do mais, demonstra como distintos contextos possibilitam, por um lado, a emergência de novos agentes engajados na construção dessas memórias e identidades, e, por outro lado, de novos sentidos ao passado.

No que se refere aos efeitos sociais do protagonismo dos laços de parentesco no movimento de Direitos Humanos e a sua incidência na política argentina contemporânea, vale problematizar as implicações da transformação das demandas desse movimento em política de Estado. Durante os governos de Néstor Kirchner e de Cristina Kirchner, foram anuladas as leis de anistia, os ex-centros clandestinos de detenção foram reabertos como espaços de memória e as lideranças das organizações de familiares de desaparecidos passaram a ser presença constante ao lado da figura do ou da presidente em atos e comemorações oficiais.

As memórias da ditadura adquiriram, desde então, maior visibilidade pública, ao passo que a condição de familiar de detenido-desaparecido, ou de afetado direto, viu-se transformada em capital social e político, em contraste com o estigma sofrido pelas vítimas durante a repressão. Isso gerou um processo de crescente incorporação de familiares e sobreviventes (os aparecidos) à política formal, seja pela eleição desses ativistas a cargos no legislativo, seja pela introdução deles no exercício de funções na Secretaria de Direitos Humanos ou em outras pastas.

Como ocorrido com as memórias da ditadura, que passaram do plano individual para o plano nacional e histórico, o trabalho de ressignificação da identidade das vítimas deixou de ser um recordatório de seus nomes e relatos de sofrimentos corporais para transformar-se numa reivindicação dos desaparecidos como atores políticos. Esses dois processos encontram-se associados, já que na definição do grupo social alvo da repressão reside também a explicação das razões e características do Proceso de Reorganização Nacional.
Há uma unanimidade em considerar que os militares buscaram definir o grupo de "inimigos" tão somente pela sua identidade política, e não étnica, racial ou religiosa; era a identidade política que determinava a categorização como "inimigo". Destaco a colocação de Crenzel (2008), quando afirma que o caráter de crime político distingue o desaparecimento forçado perpetrado na Argentina dos crimes ontológicos. Para tanto, recorre à comparação com o Holocausto, ressaltando que, enquanto para os nazistas os judeus deveriam ser destruídos pela sua condição biológica (como raça), para as Forças Armadas argentinas os subversivos poderiam ser assimilados, desde que assumissem os valores de seus captores. Como aponta Feierstein (2007), tal contraponto permite distinguir processos de aniquilamento de grupos sociais baseados em seu ser daqueles baseados em seu fazer. Essa distinção entre crimes políticos e ontológicos poderia ser corroborada por testemunhos de sobreviventes, oriundos principalmente da ESMA, que relatam as tentativas de "recuperação" de presos políticos, assim como pela apropriação de bebês para, segundo a lógica dos militares golpistas, criá-los dentro dos valores "ocidentais e cristãos da verdadeira família argentina".

Nesse sentido, o movimento de familiares entende que, para além dos desaparecidos, a ditadura se propôs a eliminar os seus ideais políticos. A militância pela memória dos tombados vê-se, assim, transformada num exercício permanente: é um dever fazê-los reaparecer (tornar os "30 mil detenidos-desaparecidos! Presentes!"), sobretudo a partir dos ideais que encarnam, já que foram desaparecidos pelos projetos políticos que defendiam. Os desaparecidos devem, portanto, permanecer vivos, como modelos de conduta para as futuras gerações.

Cabe ressaltar que não há uma continuidade linear entre a "militância dos anos 1970" e a dos familiares de desaparecidos, já que estes interpelam o Estado na qualidade de vítimas, fazendo-o a partir da linguagem dos Direitos Humanos. Ao ressignificarem os ideais dos desaparecidos, os familiares o fazem no sentido de consolidar uma memória pública sobre o passado ditatorial, visto que há um embate conformado por visões/memórias plurais que se pretendem constitutivas do imaginário nacional (Anderson, 1989).

Para além do esforço empreendido pelos familiares para atribuir um sentido à memória dos desaparecidos, existe uma disputa mais ampla, que envolve a definição do conjunto de "vítimas" da ditadura. Os familiares de militares e de membros das forças de segurança também reivindicam o estatuto de vítimas para os seus tombados, as denominadas "vítimas da subversão", assim como procuram legitimar a sua própria "verdade histórica". ${ }^{26}$ Com alguma periodicidade, atos são or- 
ganizados pela Asociación de Familiares y Amigos de Víctimas del Terrorismo en la Argentina (AFaVitA) na Plaza San Martin em Buenos Aires, onde homenageiam seus mortos e defendem a "conciliação nacional".

Num ato da AfaVitA em outubro de 2009, vale destacar a participação de Eva Donda, filha de desaparecidos. Após o desaparecimento dos pais, Eva foi criada pelo tio paterno, um militar que integrava o grupo de repressores da ESMA e que participou diretamente do sequestro de seu pai. Desde que Victoria, a irmã de Eva nascida na ESMA e apropriada por outro repressor, confirmou em 2004 o parentesco biológico com os pais desaparecidos, essas irmãs tomaram rumos diferentes e passaram a defender posições políticas antagônicas. Victoria Donda rompeu os laços com a família apropriadora, tornou-se uma ativista de H.I.J.O.S. e Abuelas, elegeu-se deputada nacional e passou a trabalhar pelas causas das organizações de familiares, tal como a aprovação da Lei de ADN. Por outro lado, Eva optava por ser voz ativa da AfaVitA, defendendo a conciliação nacional e a libertação do tio que a criou, condenado pelo crime de apropriação e outras violações aos Direitos Humanos.

O embate travado entre as irmãs Eva e Victoria Donda é emblemático de como, no contexto das disputas pela construção da memória pública sobre a ditadura, os domínios do parentesco e da política, assim como o da família e da nação, encontram-se relacionados: as partes do conflito encontrarão nos laços familiares (e biológicos) a legitimidade para defender publicamente a sua própria "verdade histórica". Vê-se também como o conflito político atravessará gerações e famílias, como no caso Donda. Enquanto os irmãos José María Donda (militante da guerrilha peronista Montoneros) e Adolfo Donda (membro do grupo de repressores da ESMA) se enfrentaram na década de 1970, as irmãs Eva e Victoria Donda representarão lados antagônicos nos embates públicos, pela afirmação de sentidos ao passado ditatorial e na defesa dos caminhos para tratar judicialmente o legado de violações.

\section{$\star \star \star$}

Ao refletir sobre o simbolismo político e processos de (re)elaboração da memória sobre o passado ditatorial, foram analisados como significados já disponíveis - noções sobre parentesco, história, identidade, autoridade, moralidade -, converteram-se em um espaço importante para a reconfiguração da experiência humana diante do evento crítico do desaparecimento forçado. $\mathrm{O}$ argumento dirigiu-se a uma abordagem da política que considera tanto a dimensão racional/instrumental quanto afetiva/existencial da ação humana (Verdery, 1999). A política foi analisada como categoria êmica, desvendando os sentidos que os familiares de desaparecidos atribuem às experiências que eles próprios entendem como políticas e examinando "as relações que indivíduos e grupos estabelecem com a história, com formas de agir e sentir identificadas com gerações anteriores, associadas a tradições" (Neiburg, 1995, p. 121).

No que se refere ao parentesco como conceitualização teórica, Piscitelli (2006) ressalta que a sua análise é considerada problemática nas sociedades contemporâneas, pois estas tendem a ser compreendidas a partir da separação da vida social em diferentes domínios (economia, política, parentesco, religião). A análise do campo de ativismo dos familiares de desaparecidos - no qual noções associadas ao parentesco articulam o âmbito da família/natural ao âmbito político/social, constituindo identidades e memórias e a sua transmissão ao longo das gerações - demonstra o sentido do parentesco em sociedades "complexas" e revela "a importância simbólica de um sistema de categorias que confere significado às experiências sociais" (Piscitelli, 2006, p. 45). Logo, com base nas abordagens mais contemporâneas dos estudos de parentesco (Schneider, 1984), este foi tratado "como uma questão empírica, não como um fato universal, partindo de uma hipótese de trabalho que indague sobre aquilo de que trata o parentesco" (Piscitelli, 2006, p. 51).

Desta forma, a perspectiva analítica pretendida aqui buscou afastar-se das discussões teóricas mais normativas, com o intuito de problematizar como noções sobre parentesco, política, memória, identidade e verdade são articuladas pelo movimento de familiares de desaparecidos. Foram explorados os significados conferidos ao parentesco no contexto da militância pelas memórias da ditadura, demonstrando como o parentesco (como dimensão afetiva da vida social) foi apropriado como instrumento político, atribuindo legitimidade às narrativas e ações políticas dos familiares de desaparecidos. $\mathrm{O}$ artigo examinou ainda como esses familiares, mediante a ressignificação dos laços de parentesco, converteram a busca pela memória material e imaterial dos tombados numa forma de perpetuar seus ideais e dar sentido ao seu legado político.

Já as polêmicas geradas pela aprovação da Lei de ADN permitiram analisar como noções sobre parentesco, sangue e verdade histórica atravessam as disputas pelas memórias da ditadura. A legitimidade do argumento que permitiu a aprovação da lei desvelou a importância do parentesco biológico na vida social. Neste sentido, o sangue e demais substâncias corporais/genéticas (o DNA), o saber científico e as vozes dos familiares tornaram-se veículos privilegiados para revelar e afirmar uma "Verdade Histórica" sobre o passado ditatorial, sobre as desaparições e apropriações. 


\section{Referências}

ABUELAS DE PLAZA DE MAYO. Las Abuelas y la Genética: el aporte de la ciencia en la búsqueda de los chicos desaparecidos. Buenos Aires: Abuelas de Plaza de Mayo, 2008.

Trascendente fallo de la Corte Suprema para conocer la identidad de los nietos apropiados. Comunicado de Prensa. Disponível em: <www.abuelas.org.ar>. Acesso em: 05 ago. 2009.

ANDERSON, Benedict. Nação e Consciência Nacional. São Paulo: Editora Ática, 1989.

BONALDI, Pablo Daniel. Hijos de Desaparecidos. Entre la construcción de la política y la construcción de la memoria. In: JELIN, Elizabeth; SEMPOL, Diego (Comps.) El Pasado en el Futuro: los movimientos juveniles. Buenos Aires/Nova York: Siglo XXI/Editora iberoamericana/ Social Science Research Council, 2006.

CATELA, Ludmila da Silva. No Habrá Flores en la Tumba del Pasado: la experiencia de reconstrucción de los familiares de desaparecidos. La Plata: Ediciones Al Margen, 2001.

. Un juego de espejos: violencia, nombres, identidades. Un análisis antropológico sobre las apropiaciones de niños durante la última dictadura militar argentina. Telar, v. 2, n. 2-3, p. 126-142, 2005.

CONADEP - Comisión Nacional sobre la Desaparición de Personas. Nunca Más. Informe de la Comisión Nacional sobre la Desaparición de Personas. Buenos Aires: Eudeba, 2009.

CRENZEL, Emilio. La Historia Política del Nunca Más. La Memoria de los Desaparecidos en la Argentina. Buenos Aires: Siglo Veintiuno Editores, 2008.

DAS, Veena. Critical Events. An Anthropological Perspective on Contemporary India. New Dheli, Oxford: Oxford University Press, 1995.

FEIERSTEIN, Daniel. El genocidio como práctica social: Entre el nazismo y la experiencia argentina. Buenos Aires: Fondo de Cultura Economica, 2007.

FEIJOO, Carmen; GOGNA, Mónica. Las mujeres en la transición a la democracia. In: JELIN, Elizabeth (Comp.) Ciudadania e Identidad: las mujeres en los movimientos sociales latino-americanos. Ginebra: UNRISD, 1987.

FILC, Judith. Entre el parentesco y la política: familia y dictadura 1976-1983. Buenos Aires: Biblos, 1997.

FRIED, Gabriela. Memorias que insisten: la intersubjetividad de la memoria y los hijos dedetenidos y desaparecidos por la Dictadura Militar Argentina (19761983). In: GROPPO, Bruno; FLIER, Patricia (Comps.) La imposibilidad del olvido: recorridos de la memoria en Argentina, Chile y Uruguay. La Plata: Ediciones Al Margen, 2001.

GELMAN, Juan; LAMADRID, Mara. Ni el flaco perdón de Dios. Hijos de Desaparecidos. Buenos Aires: Planeta, 1997.

JELIN, Elizabeth. Los Trabajos de la Memoria. Madrid/ Buenos Aires: Siglo XXI de España Editores/ Siglo XXI de Buenos Aires Editores, 2002.

Víctimas, familiares y ciudadanos/as: las luchas por la legitimidad de la palabra. Cadernos Pagu, v. 29, jul./ dez., p. 37-60, 2007.

KAUFMAN, Sharon R.; MORGAN, Lynn M. The Anthropology of the Beginnings and Ends of Life. Annual Review of Anthropology, v. 34, p. 317-341, 2005.

NEIBURG, Federico. Politização e Universidade na Argentina. Novos Estudos CEBR AP. São Paulo, n. 53, p. 119-135, mar. 1995.

Intimidad y Esfera Pública: política y cultura en el espacio nacional argentino. Vibrant, v. 1, n. 1/2, p. 230255, 2004.

PISCITELLI, Adriana. Jóias de Família: Gênero e Parentesco em histórias sobre grupos empresariais brasileiros. Rio de Janeiro: Editora URFJ, 2006.

RONIGER, Luis; SZNAJDER, Mario. O legado de violações dos direitos humanos no Cone Sul. São Paulo: Perspectiva, 2004.

SALVI, Valentina Isolda. Nem Burocratas, Nem Cruzados: militares argentinos - memórias castrenses sobre a repressão. Tese (Doutorado em Ciências Sociais). Instituto de Filosofia e Ciências Humanas, Universidade Estadual de Campinas. Campinas, SP, 2008.

. Entre el olvido yla victimización: transformaciones en la narrativa sobre la "reconciliación nacional". In: MEDVESCIG, Claudia et al. La sociedad argentina hoy frente a los años '70. Buenos Aires: Eudeba, 2010.

SARLO, Beatriz. Tempo Passado: cultura da memória e guinada subjetiva. São Paulo/Belo Horizonte: Companhia das Letras/Editora UFMG, 2007.

SCHNEIDER, David. A Critique of the Study of Kinship. Ann Arbor: The Universtity of Michigan Press, 1984.

SEMPOL, Diego. HIJOS Uruguay. Identidad, protesta social y memoria generacional. In: JELIN, Elizabeth; SEMPOL, Diego (Comps.). El Pasado en el Futuro: los movimientos juveniles. Buenos Aires: Siglo XXI Editora iberoamericana; Nueva York: Social Science Research Council, 2006.

STRATHERN, Marilyn. Reproducing the Future: Essays on anthropology, kinship and the new reproductive technologies. Manchester: Manchester University Press, 1992.

VECCHIOLI, Virginia. Políticas de la memoria y formas de clasificación social. ¿Quiénes son las víctimas del terrorismo de Estado en la Argentina? In: GROPPO, Bruno; FLIER, Patricia (Comp.) La imposibilidad del olvido: recorridos de la memoria en Argentina, Chile y Uruguay. La Plata: Ediciones Al Margen, 2001.

VERDERY, Katherine. The Political Lives of Dead Bodies: reburial and postsocialist change. New York: Columbia University Press, 1999. 


\title{
Blood, identity and historical truth: disappeared children and memories of the dictatorship in Argentina
}

\begin{abstract}
This article discusses child abduction during the latest Argentinian military dictatorship (1976-1983) and intents to understand how the members of the disappeared relatives' organizations are reconfiguring, based on their kinship with the victims of the repression, their identities and political strategies in the disputes for the definition of a public memory about the recent dictatorial past. Exploring the topic of Child Abduction through the notion of Critical Event (DAS, 1995), I analyze some national controversies regarding the process of identity restitution of the abducted grandsons of the Abuelas de Plaza de Mayo. The object of my analysis are the debates concerning the passage of the DNA Law - Lei de DNA - to solve open cases of abducted children that refuse to take the DNA test willingly. I intent to explore how notions about kinship, blood, identity and historical truth play a key-role on the disputes over the memories.
\end{abstract}

Key-words: kinship, identities, memory, politic, nation.

\section{Sangre, identidad $\gamma$ verdad histórica: niños desaparecidos $y$ memorias sobre el pasado dictatorial en Argentina}

\section{Resúmen}

En este artículo trato de la apropiación ilegal de niños durante la última dictadura militar argentina (1976-1983). Busco comprender como las organizaciones de familiares de desaparecidos, ancladas en el parentesco de sus integrantes con las víctimas de la represión, reconfiguran sus identidades y estrategias políticas en las luchas por la consolidación de una memoria pública sobre el pasado dictatorial reciente. Explorando el tema de la apropiación de niños a partir de la noción de evento crítico (DAS, 1995), analizo algunas de las polémicas nacionales que involucran el proceso de restitución de la identidad de los nietos buscados por Abuelas de Plaza de Mayo. Tomo como objeto de análisis los debates sobre la aprobación de la Ley de ADN para la resolución de los casos de los jóvenes apropiados que se rehúsan a someterse de forma voluntaria al examen de ADN. El objetivo es explorar como nociones sobre parentesco, sangre, identidad y verdad histórica están presentes en las luchas por las memorias.

Palabras-clave: parentesco, identidades, memoria, política, nación.

Data de recebimento do artigo: 6/6/2012

Data de aprovação do artigo: 30/8/2012 